(3) Map subglacial volcanic and structural features. Within or at the margins of the ice caps and outlet glaciers, a number of new glaciological, structural, and volcanic features can be mapped from ERTS-I imagery, particularly at low solar illumination angles $\left(<10^{\circ}\right)$ including several probable subglacial central volcanoes, calderas, and tectonic lineaments. Some of the effects of jökulhlaups can be mapped, including subsidence cauldrons resulting from subglacial volcanic or intense geothermal activity.

\title{
THE REMOTE SENSING OF AVALANCHE VICTIMS: PROBLEMS AND PROGRESS
}

\author{
By WiLfried Fritzsche \\ (Institut für Elektronik, Technische Hochschule in Graz, Inffeldgasse I2, A-8o 1o Graz, \\ Austria)
}

Abstract. This paper reviews possible uses of remote-sensing techniques to locate avalanche victims. Until recently probes and dogs were the only methods available, but recently attempts have been made to devise other methods for finding human beings in snow. Ideally such a search should be made possible for other members of the party, as the chance of survival of a victim falls rapidly with increasing time to rescue. For this all members of the party need to have something which the others can locate. The most usual proposal is an electromagnetic transmitter/receiver set. The merits of various possible frequencies are discussed. International agreement on a frequency is urgently required. Magnetic devices might be considered, but the detecting devices are too expensive or heavy to be generally carried. Search parties can of course be equipped with more sophisticated apparatus, and various possibilities are discussed for identifying metal on the victim, for identifying him by radio sounding, for locating him by mapping microwave emission, or for searching for eddy currents induced in him.

\section{DISCUSSION}

J. W. GLEN : Can the magnets in compasses for mountaineers be made strong enough to be usable for easy detection?

W. Fritzsche: Unfortunately not.

M. DE Quervain: Also I believe the magnetometers did not have sufficient range to be effective.

Fritzsche: This is true, but magnetic methods have not been developed to their full potential. One of the main reasons more work has not been done on them is that it seems to be impossible to develop a device like the transmitter-receiver system that will be cheap enough to distribute to all touring groups. The Förster (second harmonic) procedure was affected by temperature, and the Skifinder has problems of read-out among other things. The Skifinder and the equipment built in the Technische Hochschule Graz which are sufficiently sensitive to detect magnets to a depth of $3 \mathrm{~m}$ consist of a left and right strip each of $5 \mathrm{~m}$ width- $\mathrm{Io} \mathrm{m}$ in all. This is described in the doctoral dissertation of A. Etschmaier, Technische Hochschule Graz, ig69. 